\title{
Coastal Vulnerability Assessment towards Sustainable Management of Peninsular Malaysia Coastline
}

\author{
Mohd Fauzi Mohamad, Lee Hin Lee, and Mohd Kamarul Huda Samion
}

\begin{abstract}
The main objective of the present study is to develop a coastal vulnerability index (CVI) for the Peninsular Malaysia coastline. This study incorporated six variables to assess the CVI for the study area. These six variables consist of geomorphology, shoreline change rate, maximum current speed, maximum tidal range, significant wave height and sea level rise. The ranking is on a linear scale from 1 to 5 in order of increasing vulnerability; value 1 represents the lowest risk ranking assigned to the coastline whereas value 5 ranks the coastline with the highest risk. A total of $1963 \mathrm{~km}$ of coastline was evaluated and of this, $3.3 \%$ of the mapped shoreline is classified as being extreme vulnerability, $11 \%$ of Peninsular Malaysia shoreline is classified as very high vulnerability and $\mathbf{4 0}$ $\%$ as high vulnerability. The implementation of the Management Plan would dependent on the co-operations of the government departments and agencies, private sector and the public.
\end{abstract}

Index Terms-Coastal vulnerability index, wave height, beach materials, current speed, back shore.

\section{INTRODUCTION}

The primary causes of erosion along the shoreline can be driven by natural processes or human activities. Inadequate sediment supply to beaches and coastal inundation are among the factors contributing to coastal erosion [1]. River modifications (dams or levees), coastal structures (revetment, groynes, seawalls and jetties) and coastal minerals extraction (sand, gas, water and oil) are some agents that deplete the sediment supply to the adjacent shoreline and causing coastal erosion. Coastal inundation due to storm waves, tsunamis and sea level rise (SLR) may cause a permanent inundation to the coastal areas that will have a serious impact to the natural environment and social economic conditions in the coastal zone [2]. Over time, extensive coastal inundation will change the water quality, groundwater characteristics, increase loss of properties, potential loss of life, impact on agricultures, loss of tourism recreation and others [3].

Coastal vulnerability assessment on the existing coastline condition to withstand the natural processes and human activities was carried out to interpret the possible responses of the coastline to the boundary conditions such as SLR, human interference and inundation [4]. Thieler (1999) has completed extensive assessment of coastal vulnerability along various coastlines [5]. The researcher's assessments

Manuscript received March 10, 2014; revised May 15, 2014

The authors are with the National Hydraulic Research Institute of Malaysia (NAHRIM), Malaysia (e-mail: fauzi@nahrim.gov.my, hllee@nahrim.gov.my, kamarul@nahrim.gov.my). have incorporated six physical coastal variables such as geomorphology, shoreline change rate, coastal slope, mean tide range, mean significant wave height and SLR [2]. Table I indicates the summary of coastal vulnerability variables used by the researchers in their studies.

TABLE I: SUMMARY OF COASTAL VULNERABILITY VARIABLES USED BY

\begin{tabular}{|c|c|c|c|}
\hline Index & $\begin{array}{l}\text { Geographical } \\
\text { application }\end{array}$ & $\begin{array}{c}\text { Variables } \\
\text { consideration }\end{array}$ & Reference \\
\hline $\begin{array}{l}\text { Coastal } \\
\text { vulnerability } \\
\text { index (CVI) }\end{array}$ & USA & $\begin{array}{l}\text { Relief, rock type, } \\
\text { landform, relative } \\
\text { sea-level change, } \\
\text { shoreline } \\
\text { displacement, tidal } \\
\text { range and maximum } \\
\text { wave height }\end{array}$ & $\begin{array}{l}\text { Gornitz and } \\
\text { Kanciruk } \\
\text { (1989), } \\
\text { Gornitz } \\
\text { (1991), } \\
\text { Gornitz et } \\
\text { ala (1991) }\end{array}$ \\
\hline $\begin{array}{l}\text { Coastal } \\
\text { vulnerability } \\
\text { index (CVI) }\end{array}$ & USA & $\begin{array}{l}\text { Geomorphology, } \\
\text { shoreline erosion and } \\
\text { accretion, coastal } \\
\text { slope, relative } \\
\text { sea-level change, } \\
\text { mean wave height and } \\
\text { mean tidal range }\end{array}$ & $\begin{array}{l}\text { Thieler and } \\
\text { Hammer-K1 } \\
\text { ose (1999) } \\
\text { and } \\
\text { numerous } \\
\text { other USGS } \\
\text { reports }\end{array}$ \\
\hline $\begin{array}{l}\text { Social } \\
\text { vulnerability } \\
\text { index (SoVI) }\end{array}$ & USA & $\begin{array}{l}\text { Principal components } \\
\text { analysis of } \\
\text { Census-derived social } \\
\text { data }\end{array}$ & $\begin{array}{l}\text { Boruff et al } \\
(2005)\end{array}$ \\
\hline $\begin{array}{l}\text { Coastal social } \\
\text { vulnerability } \\
\text { score }(\mathrm{CS} 0 \mathrm{VI})\end{array}$ & USA & $\begin{array}{l}\text { Combination of CVI } \\
\text { and SOVI }\end{array}$ & $\begin{array}{l}\text { Boruff et al } \\
(2005)\end{array}$ \\
\hline $\begin{array}{l}\text { Sensitivity index } \\
\text { (SI) }\end{array}$ & Canada & $\begin{array}{l}\text { Relief, rock type, } \\
\text { landform, sea-level } \\
\text { change, shoreline } \\
\text { displacement, tidal } \\
\text { range and maximum } \\
\text { wave height }\end{array}$ & $\begin{array}{l}\text { Shaw et al } \\
(1998)\end{array}$ \\
\hline $\begin{array}{l}\text { Erosion hazard } \\
\text { index }\end{array}$ & Canada & $\begin{array}{l}\text { As SI, plus exposure, } \\
\text { storm surge water } \\
\text { level, slope }\end{array}$ & $\begin{array}{l}\text { Forebes et } \\
\text { al }(2003)\end{array}$ \\
\hline Risk matrix & South Africa & $\begin{array}{l}\text { Location, } \\
\text { infrastructure } \\
\text { (economic } \\
\text { value), hazards }\end{array}$ & $\begin{array}{l}\text { Hughes and } \\
\text { Brundrit } \\
\text { (1992) }\end{array}$ \\
\hline $\begin{array}{l}\text { Sustainable } \\
\text { capacity index } \\
\text { (SCI) }\end{array}$ & South Africa & $\begin{array}{l}\text { Vulnerability and } \\
\text { resilience of natural, } \\
\text { cultural, institutional, } \\
\text { infrastructural, } \\
\text { economic and human } \\
\text { factors }\end{array}$ & $\begin{array}{l}\text { Yamada et } \\
\text { al (1995) }\end{array}$ \\
\hline Sensitivity index & Ireland & $\begin{array}{l}\text { Shore face slope, } \\
\text { coastal features, } \\
\text { coastal structures, } \\
\text { access, land use }\end{array}$ & $\begin{array}{l}\text { Carter } \\
(1990)\end{array}$ \\
\hline $\begin{array}{l}\text { Vulnerability } \\
\text { index }\end{array}$ & UK & $\begin{array}{l}\text { Distribution event } \\
\text { frequency, relaxation } \\
\text { (recovery) time }\end{array}$ & $\begin{array}{l}\text { Pethik and } \\
\text { Croocks } \\
(2000)\end{array}$ \\
\hline
\end{tabular}




\section{Methodology}

This study has incorporated five variables to assess the coastal vulnerability Index (CVI) for the study area. These five variables consist of a) geomorphology, b) shoreline change rate, c) maximum current speed, d) tidal range, e) significant wave height and f) sea level rise. The ranking is on a linear scale from 1 to 5 in order of increasing vulnerability as shown in Table II; value 1 represents the lowest risk ranking assigned to the coastline whereas value 5 ranks the coastline with the highest risk.

TABLE II: VULNERABILITY RANKINGS FOR THE STUDY AREA

\begin{tabular}{|c|c|c|c|c|c|c|}
\hline \multirow{3}{*}{ No } & \multirow{3}{*}{ Variable } & \multicolumn{5}{|c|}{ Ranking of coastal vulnerability } \\
\hline & & $\begin{array}{l}\text { Very } \\
\text { low }\end{array}$ & Low & Moderate & High & $\begin{array}{l}\text { Very } \\
\text { high }\end{array}$ \\
\hline & & 1 & 2 & 3 & 4 & 5 \\
\hline 1 & Geomorphology & $\begin{array}{l}\text { Rocky } \\
\text { Coast }\end{array}$ & $\begin{array}{c}\text { Composite } \\
\text { of sand and } \\
\text { rocks }\end{array}$ & Sand & $\begin{array}{l}\text { Composite of } \\
\text { clay and rock } \\
\text { or sand }\end{array}$ & $\begin{array}{l}\text { Mud } \\
\text { flats }\end{array}$ \\
\hline 2 & $\begin{array}{l}\text { Shoreline } \\
\text { change rate } \\
(\mathrm{m} / \mathrm{yr})\end{array}$ & $>+8$ & +3 to +7 & -1 to +3 & -5 to -1 & $<-5$ \\
\hline 3 & $\begin{array}{l}\text { Maximum } \\
\text { current speed } \\
(\mathrm{m} / \mathrm{s})\end{array}$ & $0-0.2$ & $0.2>0.4$ & $0.4-0.6$ & $0.6-0.8$ & $0.8-1$ \\
\hline 4 & $\begin{array}{l}\text { Maximum tidal } \\
\text { range }(\mathrm{m})\end{array}$ & $>3.5$ & $3-3.5$ & $2.5-3$ & $2-2.5$ & 0 \\
\hline 5 & $\begin{array}{l}\text { Significant wave } \\
\text { height }(\mathrm{m})\end{array}$ & $<0.5$ & $0.7-1.4$ & $1.4-2.1$ & $2.1-2.8$ & $>5$ \\
\hline 6 & $\begin{array}{l}\text { Sea level rise } \\
(\mathrm{mm} / \mathrm{yr})\end{array}$ & $<1.8$ & $1.8-2.5$ & $2.5-3$ & $3-3.4$ & $>3.4$ \\
\hline
\end{tabular}

\section{A. Geomorphology}

The geomorphology variable expresses the relative erodibility of different landform types. Coastal vulnerable rank of 1 represents the lowest risk for erodibility such as a rocky coastline, whereas a ranking of 5 represents the highest risk of erodibilty to the coastline. Labuan Island shorelines consist of six main beach materials; those beach materials can be categorized as muddy, muddy and rocky, muddy and sandy, sandy, sandy and rocky and rocky.

\section{B. Shoreline Change Rate (m/year)}

The approach involves comparing the trend of shoreline changes observed in two sets of images. Comparison of images from aerial photographs from year 2008 and topography maps from year 1975 were used in this study. The difference in shoreline changes measured in metres, from these two images was divided by 34 to calculate the eroding or accreting rate occurring at a particular shoreline. Higher erosion rates at a specified shoreline location indicate a more vulnerable coastline at the location and this location is assigned a higher ranking.

\section{Maximum Current Speed $(\mathrm{m} / \mathrm{s})$}

Numerical model analysis on the tidal induced current along the Peninsular Malaysia shoreline was simulated with respect to determining the maximum current speed for correlating with the potential rate of shoreline retreat and tidal fluctuation elevations as an input in the boundaries conditions. Shorelines with current speeds lesser than approximately $0.2 \mathrm{~m} / \mathrm{s}$ can be categorized as having a low risk to shoreline vulnerability (JPBD, PP 2001), hence was ranked 1 and current speeds greater than $0.8 \mathrm{~m} / \mathrm{s}$ was ranked 5.

\section{Tidal Range ( $m$ )}

Tidal range is the differential tidal elevations between the highest and lowest tidal elevations which occur at a particular point in the ocean. Peninsular Malaysia consists of three types of tides namely, diurnal, semi-diurnal and mixed tide. Some studies have reported that shoreline with bigger tidal range was less vulnerable to sudden storm surges, putting the shoreline in a less vulnerable position. Consequently a tidal range greater than $3.5 \mathrm{~m}$ was classified as having a low vulnerability and was ranked 1 .

\section{E. Significant Wave Height (m)}

Spectral wave simulation was developed to determine the significant wave heights along the study areas. The higher the significant wave height is deemed to make the shoreline more vulnerable to erosion, so the ranking was higher compared to lower wave heights propagation at a shoreline.

\section{F. Sea Level Rise (mm/year)}

Tidal fluctuations analysis for 22 tidal stations with up to 24 years tidal duration records from Department of Survey and Mapping Malaysia (JUPEM) was performed and the findings from the analysis shows that Malaysia is affected by global warming with varying degrees of sea level rise. The higher sea level rise induced the more vulnerable a particular shoreline will be and thus was assigned with a higher ranking value.

\section{G. The Coastal Vulnerability Index (CVI)}

Once each section of the coastline has been assigned a vulnerability value for the specific assessment variable, the CVI can be calculated as the square root of the product of the ranked variables divided by the total number of variables.

$$
\mathrm{CVI}=\sqrt{ }(a 1 \times a 2 \times a 3 \times a 4 \times a 5 \times a 6) / 6
$$

where $a 1=$ geomorphology, $a 2=$ shoreline change rate $(\mathrm{m} / \mathrm{yr})$, $a 3=$ maximum current speed $(\mathrm{m} / \mathrm{s}), a 4=$ maximum tidal range (m), a5=significant wave height $(\mathrm{m})$ and $a 6=$ sea level rise in Peninsular Malaysia (mm/yr).

\section{RESULT}

\section{A. Geomorphology}

As mentioned in paragraph 2.1 earlier, Malaysia's shoreline consists of 6 major beach materials; the Straits of Malacca shoreline is mostly muddy material, however patches of sandy beaches is to be found from the Negeri Sembilan shoreline to parts of the Malacca shoreline. Most of the islands along the Straits of Malacca consist of sandy beaches. The east coast of Peninsular Malaysia comprised of sandy beaches at the northern stretches and at the southern reaches, the shorelines composed of sandy and rocky beach materials. Fig. 1 illustrates the distribution of the beach materials along the shoreline. 


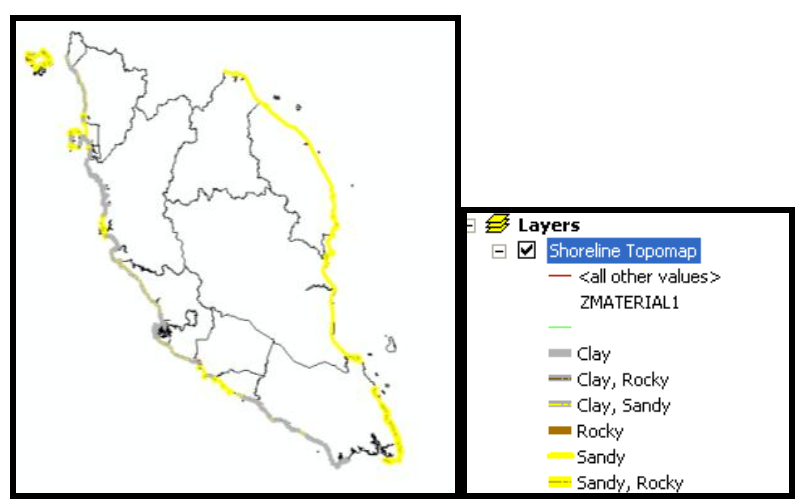

Fig. 1. Illustrates the distribution of beach material types along the shoreline.

Coastal geomorphology variables were evaluated to categorize the seriousness of the beach material in causing a vulnerable situation to occur at the shoreline. Fig. 2 shows the geomorphology ranking for the entire peninsular shoreline, with high risk shorelines located at the Straits of Malacca.

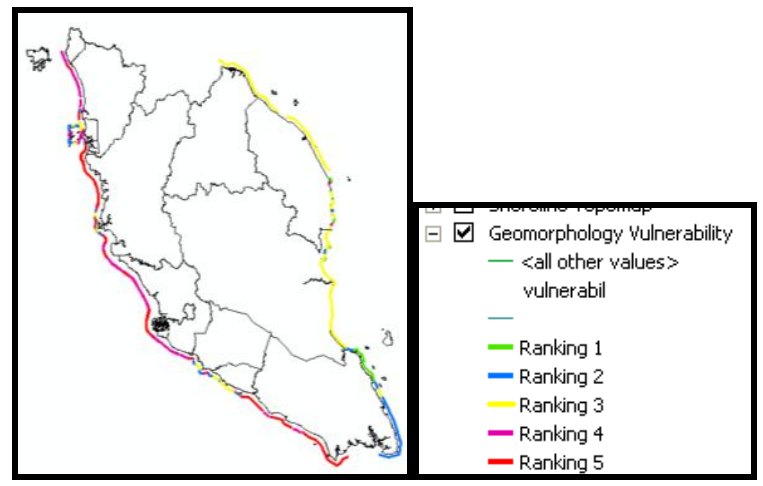

Fig. 2. Coastal geomorphology vulnerable ranking.

\section{B. Shoreline Change Rate ( $\mathrm{m} /$ year)}

Shoreline changes assessment was carried out by comparing the shoreline position in the years 1975 and 2008. Fig. 3 on the left, shows the shoreline conditions for both years (red represents 2008 while black represents 1975), whereas shoreline erosion/deposition ranking vulnerability is displayed at Fig. 4. Stretches from Tg. Piadang to Port Klang at the north, the Senggarang beaches to Tg. Piai at the south and Pekan, Pahang were identified as having badly eroded shoreline with erosion rates ranging from $-3 \mathrm{~m} /$ year to $-5 \mathrm{~m} /$ year and for some places it was more than $5 \mathrm{~m} /$ year.

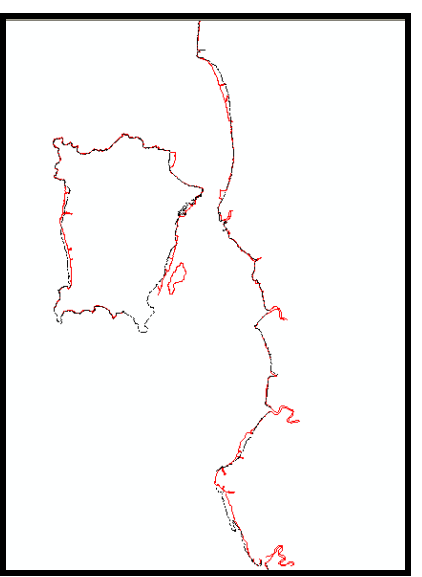

Fig. 3. Comparison of Penang Island shoreline condition for year 1975 (black) and 2008 (red)

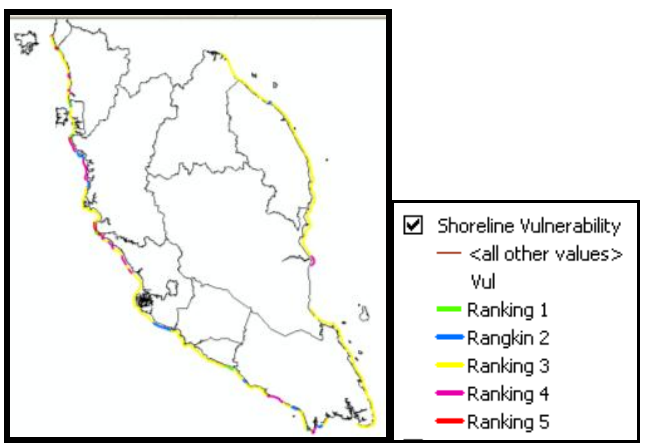

Fig. 4. shoreline changes vulnerability ranking.

\section{Maximum Current Speed $(\mathrm{m} / \mathrm{s})$}

The east coast of Peninsular Malaysia is exposed to higher current speeds compared to the west coast. In the Straits of Malacca the southern stretches are more vulnerable compared to northern stretches. Fig. 5 presents the maximum current speed condition, whereas Fig. 6 displays the current speed vulnerability ranking for the study areas.

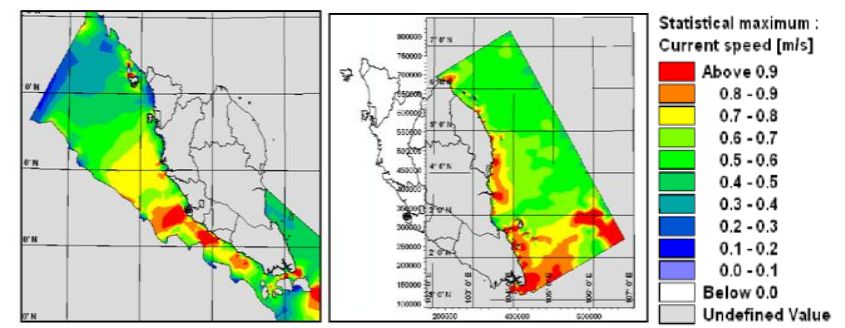

Fig. 5. Comparison of maximum current speeds on the west and east coasts of Peninsular Malaysia.

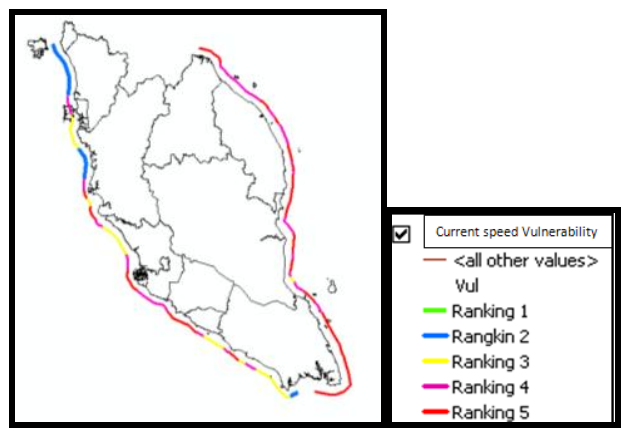

Fig. 6. Maximum current speed vulnerability ranking.

\section{Maximum Tidal Range $(m)$}

Port Klang in Selangor and Pekan in Pahang have a greater tidal range for the west coast and east coast of Peninsular Malaysia, respectively. Thus these two places are categorized as less vulnerable in the ranking. Fig. 7 compares the maximum tidal range for the west coast and east coast of Peninsular Malaysia, whereas Fig. 8 illustrates the tidal range vulnerability rankings.

\section{E. Significant Wave Height (m)}

The east cost of Peninsular Malaysia is exposed to higher waves generated from the South China Sea, whereas the Straits of Malacca is sheltered by Sumatra Island on the west, thus the wave heights at the west coast of Peninsula Malaysia is lower. The width of the Straits of Malacca is narrower at the southern stretches the waves from the wake effects from moving sea-going vessels play an important role, however 
this study has not considered this effect in its hydrodynamic wave modelling. Fig. 8 presents the maximum significant wave heights at the study areas and Fig. 9 and Fig. 10 show the wave height vulnerability rankings.

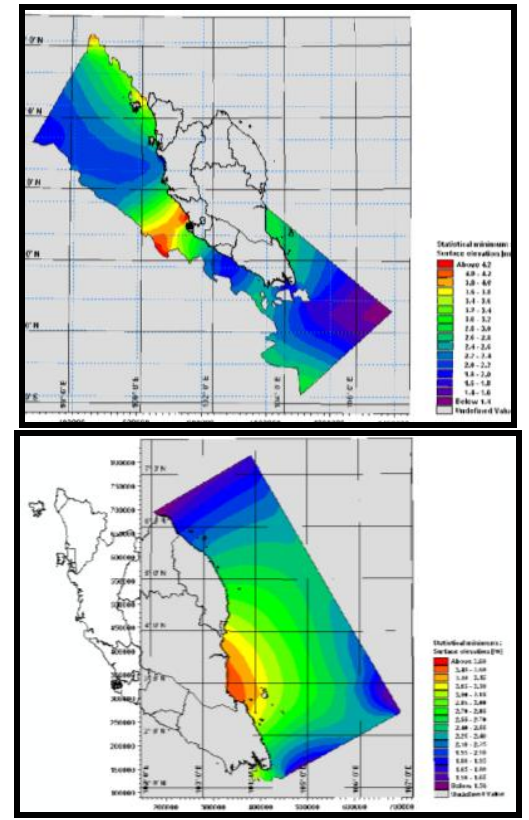

Fig. 7. Maximum tidal range on the west coast (top) and east coast (bottom) of Peninsular Malaysia.

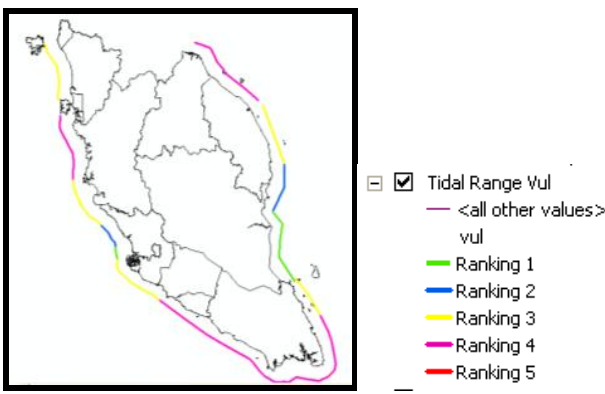

Fig. 8. Tidal range vulnerability rankings.

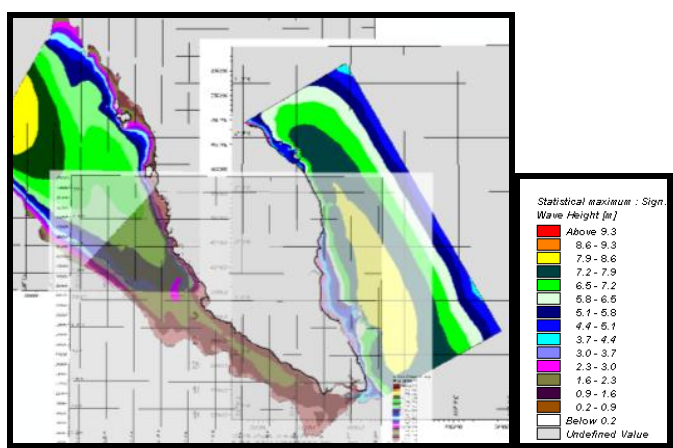

Fig. 9. Maximum wave heights along Peninsular Malaysia's shoreline.

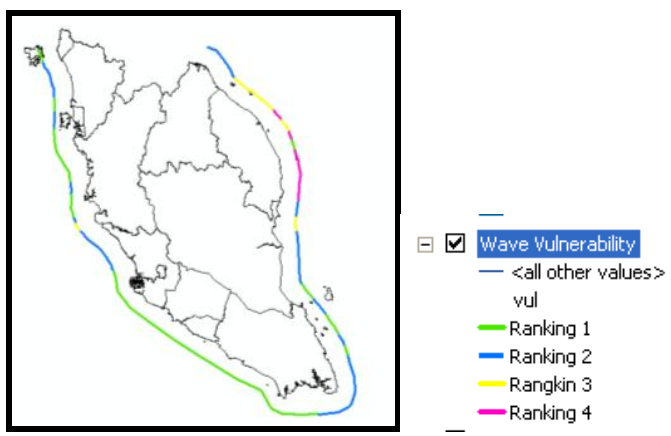

Fig. 10. Wave vulnerability rankings.

\section{F. Sea Level Rise ( $\mathrm{mm} /$ Year)}

Long term records from 21 tide stations monitored by the Department Of Survey and Mapping Malaysia (JUPEM) are used in this study. Findings from the analysis identified clearly that a non-uniform rate of sea level rise occurs along the Malaysian coastline, with some regions showing a sea level rise more than the global average, while other regions indicated a sea level fall. This may be due to land subsidence effect which has not been considered in this study. However this study has not considered land subsidence. Fig. 11 shows the mean annual sea level rise per year (mm/year). Fig. 12 illustrates the sea level rise vulnerability rankings.

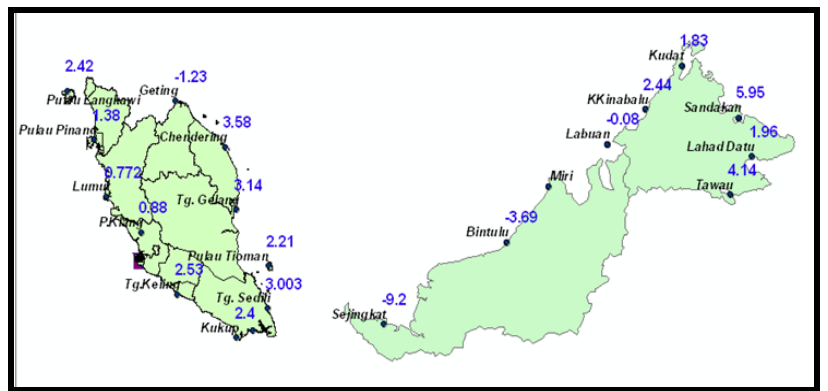

Fig. 11. Mean annual sea level rise (mm/year).

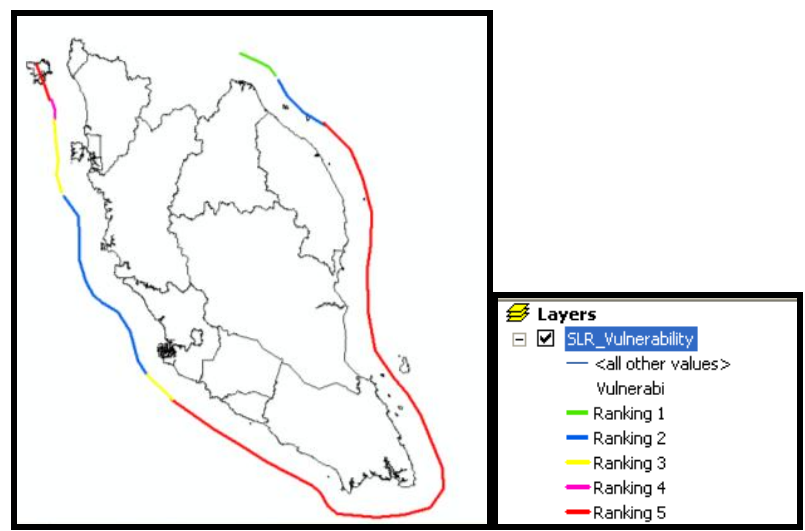

Fig. 12. Sea level rise vulnerability rankings.

\section{SUMMARY OF CVI}

After assigning the risk value on the specific data variables to each section of the coastline, the CVI was calculated using Eq. (1), result indicates CVI for Peninsular Malaysia ranging from 4.2 to 24.5. Finally this CVI is divided into low, moderate, high, very high and extreme vulnerability categories. Based on the breakdown a value below 6.5 is categorized as low vulnerability (category 1), from 6.5 to 10.5 is considered moderate vulnerability (category 2), high-vulnerability CVI values lie between 10.5 to 14.6 (category 3), whereas 14.6 to 18.5 is specified as very high vulnerability (category 4 ) and a value above 18.5 is classified as extreme vulnerability (category 5).

A total of $1963 \mathrm{~km}$ of coastline was evaluated and of this, $3.3 \%$ of the mapped shoreline is classified as category 5 , these sites are southern stretches of Terengganu shoreline and northern reaches of Kedah shoreline. Results have shown that $11 \%$ of Peninsular Malaysia shoreline is classified as category 4 and $40 \%$ as category 3 . Fig. 13 and 14 shows the results of the CVI Map for the study area which illustrates the percentage breakdown on the shoreline CVI. 


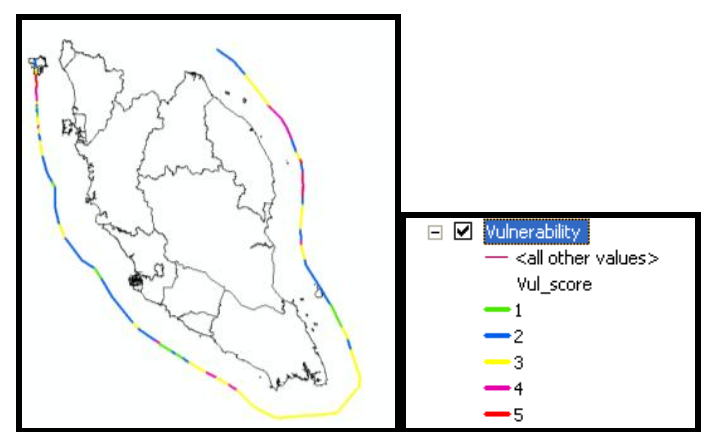

Fig. 13. Show the CVI Map for the study area.

\section{Peninsular Malaysia Shoreline Vulnerability Index}

Low $\square$ Moderate $\quad$ High $\square$ Very High $\square$ Extreme

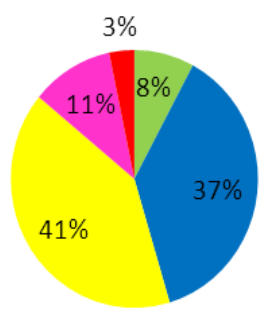

Fig. 14. Percentage of Peninsula Malaysia CVI.

\section{Coastal Erosion And Sedimentation Management PLAN}

The coastal environment management plan is formulated to guide the planning of development for the peninsular shoreline. The sensitivity of the shoreline on particular conditions such as natural environment and usage needs the right management planning to optimise its full potential. The findings on coastal processes shall formulate proposals to protect, maintain and enhance the shoreline.

\section{A. Identify and Classify}

For the eroding coastline areas, a monitoring programme to determine that the erosion is a net event is required. An inventory of the coastline should be created and the rate of erosion per year will determine the timing of the engineering solution. The purpose of carrying out a Detailed Coastal Erosion Inventory is to identify priority stretches that require attention in terms of conducting a study to determine appropriate stabilisation solutions and development that are feasible to be carried out. This systematic approach will provide a good tool for decision making to implement solutions in a timely manner.

It is vital that any development that is intended to be carried out have to consider the indirect impacts arising from these sea environment parameters. Site specific development could be planned for the various development requirements such as port, recreational or linear park development taking into account the sea environment rankings and coastal rankings. This will then assist and ease the process of feasibility studies where the knowledge of impacts at certain areas captured in this Study would give preliminary indications on the sea environment and its impacts on the coastline.

\section{B. Carry out Detailed Study for Engineering Solutions}

A detailed study of any development in the vicinity of the coastal area has to be carried out. The macro scale analysis performed in this Study by utilising the numerical modelling methods can only give an indication of potential impacts. Notwithstanding the above, the macro study has shown that development is possible and impacts can be mitigated. In order to derive benefit in the long run, a thorough study needs to be implemented and a development plan can only be optimised via a detailed study.

Moreover, in view of stabilising the coastline, measures such as breakwater, groyne, revetment, beach nourishment and artificial reef could be explored. Knowing the stretches that are vulnerable will provide the authorities key information to plan for allowing sufficient annual financial budget to carry out physical works. Each of the eroding coastline reaches could be weighted on the estimated cost benefit and the timeframe to carry out the physical works. The CVI has given indications of possible coastal stretches that are affected by erosion which are to be given priority for remediation.

\section{Develop and Implement Coastal Protection Monitoring}

The rate of erosion differs along the shoreline. The inventory will indicate the critical reaches or sub-reaches to be attended to. It is understood that financial constraints will also govern the decision making and it is therefore all the more important that the monitoring activity is carried out.

The coastal monitoring will give the authorities a lead time before any major disaster or loss of precious land could occur at the coastline. Beach profiling of the identified coastal reaches at an interval of every three (3) months, will give an accurate rate of erosion as well as an indication of the severity with respect to time. Seasonal change also could be captured in this monitoring works and would further strengthen the observations. The action plan will give the authorities valuable lead time and estimation of timely disbursement with regards to the ranking of priority areas to be attended to.

\section{Identify and Classify Coast According to Forces}

The hydrodynamic conditions of the surrounding coastline play an important role. For instance, the wave and current will have a great influence on the erosion and accretion. Wave generating winds over the surface of the sea, or fetch length, could increase the wave heights depending on the length of the sea area before land is reached.

The dominant parameter does not render that any development could not take place, it however indicates that emphasis on the forces need to be catered for and the adverse impact on the development as well as the environment could be mitigated early during the planning stage.

It is proposed to carry out a detailed numerical study to project the impact of the hydrodynamic and near shore waves on currents scenario. This will give an indication of changes over a range of average recurrent interval (ARI) and possible deterioration of conditions if no measures are implemented. This prediction will help the relevant agencies to appreciate that development at certain cells are not feasible due to the 
high cost of mitigation.

\section{E. Rehabilitation Measures}

Rehabilitation of coastal erosion should also be integrated in engineering study. It is common scenario that development protruding out of the existing shoreline will experience accretion and also erosion adjacent to the development.

The engineering study should also be looking at the maintenance phase of the development. Periodic tasks that are required based on the design of the development should be incorporated. For example, a development for public beach and facilities may require periodic task of recharging it with beach materials, beach combing, waste collection and other tasks to ensure that pollutions and sustainability of the development are thoroughly taken care of.

The crucial thing for design is to appreciate the fundamental characteristics of the site. Any development must suit the environment of the area proposed. Thus, prior understanding of the projected waves, currents and winds at the coastal area is crucial in coastal areas. Any mitigation proposed should ensure that proper steps are taken to minimise the impact of development.

The next step would be to implement the mitigation measures corresponding to it. It should also be possible to explore other mitigation actions that could be implemented such as maintaining coastal vegetation during the construction phase as a natural barrier or rehabilitate the vegetation at buffer zones to prevent degradation.

However, it should be noted that the mitigation measures will correspond to the impact that will be experienced by the coastal cell. Improvement in mitigation measure should be explored once the development is identified and further study has been carried out to assess the interaction between the environmental forces and the proposed development.

Implementing mitigation measures without proper refining may incur cost overruns. This is true if for instance, the length of breakwater arms was too short that it does not block the wave that might pose danger to the development. Or, the breakwater arms are too long that it is has no significant benefit to the development. Thus, the mitigation measure would need proper refining to suit the final scheme of development.

\section{SUMMARY}

Peninsular Malaysia shoreline is vulnerable to the natural processes such as wind induces wave, tidal current, global sea level rise and others. Analysis on the six variables namely geomorphology, shoreline change rate, maximum current speed, maximum tidal range, significant wave height and sea level rise, indicated that southern stretches and eastern reaches of the Peninsular Malaysia shoreline is in vulnerable position. The implementation of the Management Plan would dependent on the co-operations of the government departments and agencies, private sector and the public.

\section{REFERENCES}

[1] R. A. Morton, "An overview of coastal land loss: with emphasis on the south eastern United States," U.S. Geological Survey, Open File Report 03-337, 2003.
[2] G. S. Dwarakish, S. A. Vinary, U. Natesan et al., "Coastal vulnerability assessment of the future sea level rise in Udapi coastal zone of Karnataka State, west coast of India," Ocean and Coastal Management, vol. 52, pp. 467-478, 2009

[3] D. J. Doong, T. W. Hsu, L. Ch. Wu, and C. C. Kao, "Sea level rise at East Asia coasts based on tide gauge analysis," in Proc. the Nineteenth International Offshore and Polar Engineering Conference, 2009.

[4] M. L. Capobiancoo, H. D. Vriend, R. Nicholas et al., "Coastal area impact and vulnerability assessment: The point of view of a morpholodynamic modeller," Journal of Coastal Research, vol. 15, no. 3, pp. 701-16, 1999

[5] E. R. Thieler and E. S. Hammar-Klose, "National assessment of coastal vulnerability to future sea-level rise: Preliminary results for the U.S Atlantic Coast," U.S. Geological Survey, Open File Report 99-593, 1999.

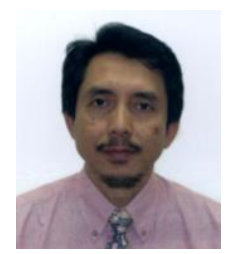

Mohd Fauzi M. was born in 1959. He holds a diploma degree in civil engineering from Institut Teknologi Mara, Malaysia in 1981, a bachelor degree of science (Hons) from civil engineering at University of Strathclyde, United Kingdom in 1983 and a master degree in hydrology and water resources at Universiti Teknologi Malaysia in 2009.

He had served at Jabatan Kerja Raya (JKR) from 1983 to 2001, before serving National Hydraulic Research Institute of Malaysia (NAHRIM) from 2001 to present. At JKR, he held positions of senior executive engineer before serving at NAHRIM as a senior researcher on coastal engineering division on 2001 to 2003 and Director of Hydraulic and Instrumentation Laboratory from 2003 until now.

Ir. Mohd Fauzi have vast experience in project management and structural design with major in coastal structures during his tenure in JKR and has produces several research technical papers. He is a professional engineer, member of board of Engineer Malaysia (BEM); and corporate member of Institution of Engineer Malaysia (IEM).

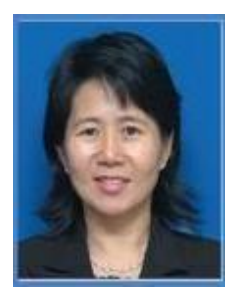

Lee Hin Lee was born in 1964. She holds a bachelor degree of Eng (Hons) in civil engineering at University Hanyang, Korea in 1988, and a master degree in coastal processes at Universiti Kebangsaan Malaysia in 2010.

She had served at Jabatan Pengairan dan Saliran (JPS) from 1989 to 2003, before serving National Hydraulic Research Institute of Malaysia (NAHRIM) from 2003 to present. At JPS, she held positions of senior executive engineer before serving at NAHRIM as a senior researcher on coastal engineering division on 2003 until now.

Lee Hin Lee is a senior researcher in coastal engineering and coastal numerical modelling, particularly in hydrodynamic and sediment coastal processes. Her experiences and capabilities are demonstrated by her involvement as adviser to federal and Malaysia state government agencies related to coastal engineering processes, coastal reclamation works, coastal development strategies and morphology processes in mangrove replanting works. She is a professional engineer, member of board of Engineer Malaysia (BEM); and corporate member of Institution of Engineer Malaysia (IEM).

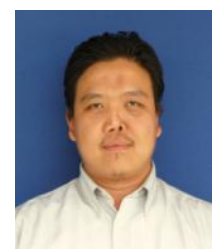

Mohd Kamarul Huda S. was born in 1980 and holds a bachelor degree of Eng. (Hons) in civil engineering at UTM, Mal in 2003, and a master degree of science in Hydraulic \& Hydrology at University Technology Malaysia in 2006.

He had serving National Hydraulic Research Institute of Malaysia (NAHRIM) from 2007 to present At NAHRIM, he held positions of senior research officer on laboratory of hydraulic and instrumentation until now.

$\mathrm{He}$ is currently a researcher in charge of hydraulic and hydrological mode testing project particularly in flood mitigation study and hydraulic structure. He had carried out numerous physical modelling for many rivers, dam and coastal in Malaysia. 